\title{
Penerapan Kompres Hangat Menggunakan Jahe Merah Untuk Menurunkan Nyeri Pada Lansia Dengan Gout Arthtritis
}

\author{
Putri Isnayanti ${ }^{1 *}$, Herni Rejeki ${ }^{2}$ \\ ${ }^{1,2}$ Program Studi Diploma Tiga Keperawatan, Universitas Muhammadiyah Pekajangan \\ Pekalongan, Indonesia \\ *email: putriisnayanti@gmail.com
}

\begin{abstract}
Gout Arthtritis is a disease, often occurs in the elderly. The symptoms are swelling, redness, heat and pain at night. One of the ways to overcome the disorder is by warm compressing using red ginger. This study aims to apply warm compress using red ginger in reduding pain. To be known, it focused two elderly with gout arthtritis. The result shows by applying the technique, it reduced a pain scale in the fifth meeting. From the first client, it can reduce a pain scale of 9 to 2 . Meanwhile, it can reduce a pain scale of 8 to 3 from the second one. The conclusion is the warm compress technique using red ginger could reduce a pain scale in the elderly with gout arthtritis. Therefore, it is expected to apply this technique regularly.
\end{abstract}

Keywords: Gout arthtritis; Warm compress using red gingers; Elderly; Pain

\begin{abstract}
Abstrak
Gout arthtrtitis merupakan penyakit yang sering terjadi pada lansia. Gejala dari gout arthtrtitis itu sendiri yaitu terjadi pembengkakan, kemerahan, timbul rasa panas dan nyeri pada malam hari, untuk meringankan rasa sakit tersebut. Salah satu tindakan dengan terapi non farmakologi yang dapat dilakukan untuk menurunkan nyeri adalah teknik kompres hangat menggunakan jahe merah. Studi kasus ini bertujuan untuk menerapkan kompres hangat menggunakan jahe merah dalam menurunan nyeri. Fokus studi kasus yaitu pada 2 lansia dengan masalah gout arthritis. Hasil studi kasus menunjukkan teknik kompres hangat menggunakan jahe merah dapat menurunkan skala nyeri pada pertemuan ke 5 . Klien pertama dari skala nyeri 9 menjadi 2, sedangkan klien yang kedua dari skala nyeri 8 menjadi 3. Kesimpulannya adalah bahwa teknik kompres hangat menggunakan jahe merah dapat menurunkan skala nyeri pada lansia dengan gout arthtritis. Saran bagi pasien untuk melakukan teknik kompres hangat menggunakan jahe merah dengan rutin dan teratur.
\end{abstract}

Kata kunci : Gout Arthtritis; Kompres hangat jahe merah; Lansia; Nyeri

\section{Pendahuluan}

Menurut UU no 13 tahun 1998, lansia adalah seseorang yang usianya lebih dari 60 tahun keatas. Perubahan yang banyak terjadi pada lansia mempunyai karakteristik seperti kulit kendur, rambut beruban, perubahan sistem sensori, serta terjadi perlambatan aktivitas (Padila, 2017) [1]. Masalah kesehatan pada lansia yang sering terjadi yaitu salah satunya gout arthtritis karena usia semakin bertambah akan mengakibatkan terjadinya proses penuaan dan terjadi banyak perubahan fisik dan biologis yang berakibat lansia rentan terkena gout arthtritis. Gout arthtritis itu sendiri merupakan peningkatan kadar purin yang melebihi batas normal sehingga memicu peningkatan kadar gout arthtritis dalam darah. Ibu jari, telapak kaki, lutut merupakan merupakan bagian tubuh yang sering mengalami gout arthtritis dengan tanda dan 


\section{Prosiding Seminar Nasional Kesehatan $\mathbf{2 0 2 1}$ Lembaga Penelitian dan Pengabdian Masyarakat Universitas Muhammadiyah Pekajangan Pekalongan}

gejala akan merasakan nyeri pada persendian pada malam hari atau pagi hari, pembengkakan, kemerahan, panas, kesemutan, linu serta tidak alergi jahe merah (Haryono \& Setianingsih, 2013) [2].

Prevelensi penyakit sendi di Indonesia diperkirakan pada usia lebih dari 75 tahun sebesar $(18,9 \%)$, usia $65-74$ tahun sebesar $(18,6 \%)$ dan usia 55-64 tahun sebesar $(15,55 \%)$. Jika dilihat dari karakteristik umur, prevelensi tertinggi pada umur lebih dari 75 tahun. Prevelensi ini meningkat seiring dengan meningkatnya umur (Rikerdas, 2018) [3].

Cara untuk menurunkan nyeri gout arthtritis ada dua cara yaitu secara farmakologis dan secara non farmakologis. Pemberian obat anti inflamasi nonsteroid (OAINS) seperti naproxen ibuprofen dan allopurinol merupakan terapi farmakologis yang dilakukan (Zuriati, 2017 dalam Ilham, 2020). Pengobatan non farmakologis yang dapat dilakukan untuk menurunkan nyeri gout arthtritis yaitu diet purin, kompres hangat menggunakan jahe merah. Jahe itu sendiri memiliki kandungan oleoresin yang memiliki efek rasa panas sehingga dapat melebarkan pembuluh darah (Rusnanto dkk, 2015, dalam Ilham, 2020) [4].

Berdasarkan hasil studi kasus ditemukan 4 orang yang menderita gout arthtritis dari 10 orang yang sudah dites kadar gout arthtritis. Keempat klien mengatakan bahwa belum pernah mendapatkan terapi kompres hangat menggunakan jahe merah untuk mengurangi nyeri sendi. Oleh karena itu, penulis tertarik untuk melakukan studi kasus tentang "penerapan kompres hangat menggunakan jahe merah untuk menurunkan nyeri pada lansia dengan gout arthtritis".

\section{Metode}

\section{Jenis Studi Kasus}

Rancangan karya tulis ilmiah ini adalah deskriptif dalam bentuk studi kasus. Studi kasus merupakan bentuk studi kasus tentang lingkungan social termasuk juga manusia di dalamnya yang mendalami secara mendalam. Studi kasus ini dilakukan dengan mencocokan pola, membangun penjelasan, serta model logis dan hasil dari pembahasan kasus ini nantinya di temukan beberapa hal yang mempengaruhi keberhasilan terapi kompres hangat menggunakan jahe merah.

\section{Lokasi dan Waktu Penelitian}

Studi kasus ini telah dilakukan di Desa Jetak Lengkong Rt 002/ Rw 001, Kecamatan Wonopringgo, Kabupaten Pekalongan, dimulai dari bulan Februari sampai Maret 2021.

\section{Populasi dan Sampel}

Pengambilan sampel menggunakan Non probability sampling dengan teknik Purposive sampling, jumlah sampel pada penelitian ini sebanyak 4 responden sesuai kriteria sampel. Pengambilan data dilakukan dengan menyeleksi calon responden yang sesuai dengan kriteria sampel. Instrumen yang digunakan adalah jahe merah, parut, kassa dan lembar observasi numeric rating scale (NRS). 


\section{Prosiding Seminar Nasional Kesehatan Lembaga Penelitian dan Pengabdian Masyarakat Universitas Muhammadiyah Pekajangan Pekalongan}

\section{Hasil dan Pembahasan}

\section{Hasil}

Berdasarkan hasil studi kasus didapatkan data demografi sebagai berikut :

Tabel 3.1 Distribusi frekuensi responden berdasarkan jenis kelamin di desa Jetak Lengkong Kabupaten Pekalongan

\begin{tabular}{ccc}
\hline Jenis kelamin & Frekuensi & Persentasi\% \\
\hline Laki- laki & 1 & 10,0 \\
Perempuan & 9 & 90,0 \\
\hline Total & 10 & 100.0 \\
\hline
\end{tabular}

Tabel 3.2 Distribusi frekuensi responden berdasarkan usia di desa Jetak Lengkong Kabupaten Pekalongan

\begin{tabular}{ccc}
\hline Jenis kelamin & Frekuensi & Persentasi\% \\
\hline 60- 74 tahun & 3 & 30,0 \\
45-59 tahun & 7 & 70,0 \\
\hline Total & 10 & 100.0 \\
\hline
\end{tabular}

Tabel 3.3 Distribusi frekuensi responden berdasarkan responden yang menderita nyeri gout arthtritis dan diberikan kompres hangat menggunakan jahe merah di desa Jetak Lengkong Kabupaten Pekalongan

\begin{tabular}{ccc}
\hline Jenis kelamin & Frekuensi & Persentasi\% \\
\hline Laki-laki & 1 & 50,0 \\
perempuan & 1 & 50,0 \\
\hline Total & 2 & 100.0 \\
\hline
\end{tabular}

Tabel 3.4 Distribusi perbedaan skala nyeri gout arthtritis responden sebelum dan sesudah dilakukan kompres hangat menggunakan jahe merah di desa Jetak Lengkong Kabupaten Pekalongan 24 -29 Maret 2021

\begin{tabular}{ccccc}
\hline $\begin{array}{c}\text { Nama } \\
\text { responden }\end{array}$ & Hari & $\begin{array}{c}\text { Skala nyeri } \\
\text { (pre) }\end{array}$ & $\begin{array}{c}\text { Skala nyeri } \\
\text { (post) }\end{array}$ & $\begin{array}{c}\text { Penurunan } \\
\text { skala nyeri }\end{array}$ \\
& 1 & 9 & 9 & 0 \\
& 2 & 9 & 8 & 1 \\
& 3 & 8 & 6 & 2 \\
& 4 & 6 & 4 & 2 \\
Mean & 5 & 4 & 2 & 2 \\
\hline
\end{tabular}




\begin{tabular}{ccccc}
\multicolumn{4}{c}{ Prosiding Seminar Nasional Kesehatan } \\
Lembaga Penelitian dan Pengabdian Masyarakat \\
Universitas Muhammadiyah Pekajangan Pekalongan \\
\hline Nama & Hari & Skala nyeri & Skala nyeri & Penurunan \\
responden & \multicolumn{5}{c}{ (pre) } & (post) & skala nyeri \\
Tn.D & 1 & 8 & 8 & 0 \\
& 2 & 8 & 7 & 1 \\
& 3 & 7 & 5 & 2 \\
& 4 & 5 & 4 & 1 \\
\hline Mean & 5 & 4 & 3 & 1 \\
\hline
\end{tabular}

Sumber : Data Primer

Berdasarkan Tabel 4 menunjukan bahwa 2 responden yang memenuhi kriteria serta mengalami gout arthtrtitis sebelum dilakukan tindakan kompres hangat menggunakan jahe merah memiliki rata- rata skala nyeri pada kasus 1 yaitu 7,2 (nyeri berat) dengan skala nyeri tertinggi 9 (nyeri berat) dan skala nyeri terkecil sebesar 4 (nyeri sedang), sedangkan setelah dilakukan tindakan kompres hangat menggunakan jahe merah memiliki rat-rata skala nyeri sebesar 5,8 (nyeri sedang) dengan skala nyeri terbesar 9 (nyeri berat) dan skala nyeri terendah yaitu 2 (nyeri ringan).

Sedangkan pada kasus 2 rata-rata sebelum dilakukan tindakan kompres hangat menggunakan jahe merah yaitu 6,4 ( nyeri sedang) dengan skala nyeri tertinggi 8 (nyeri berat) dan skala nyeri terkecil sebesar 4 (nyeri sedang). Setelah dilakukan kompres jahe merah rata-rata menjadi 5,4 (nyeri sedang) dengan skala nyeri tertinggi 8 (nyeri berat) dan skala nyeri terkecil 3 (nyeri ringan).

\section{Pembahasan}

Berdasakan pada tabel 4 menunjukan bahwa dari 10 responden penderita gout arthtritis terdapat 2 responden yang memenuhi kriteria untuk diberikan tindakan kompres hangat menggunakan jahe merah. Sebelum dilakukan tindakan kompres hangat menggunakan jahe merah kedua responden memiliki rata-rata nyeri sebesar 7,2 (nyeri berat) dan 6,4 (nyeri sedang).

Penerapan teknik kompres hangat menggunakan jahe merah memiliki efek panas dan pedas dari jahe merah itu yang menyebabkan terjadinya vasodilatasi pembuluh darah yang menyebabkan penurunan nyeri dengan menghilangkan zat yang membuat infamasi seperti bradikinin, histamine dan prostaglandin yang menimbulkan nyeri (Kumar, 2013 dalam Radharani, 2020) [5]. Efek rasa panas akan merangsang sel saraf menutup sehingga transmisi impuls nyeri ke medulla spinalis dan otak sehingga bisa terhambat. Serta kandungan jahe yaitu 6-gingerdiom, 6-gingerol, zingerol yang berfungsi menekan prostaglandin melalui hambatan pada aktivitas COX-2 yang menghambat produksi PGE2 dan leukotriene dan TNF pada sinoviosit dan sendi manusia (Nahed \& Tavakkoli, 2015 dalam Radharani, 2020) [5]. Kandungan tersebut yang dapat menurunkan nyeri pada klien gout arthtritis. Penerapan kompres hangat menggunakan jahe merah yang dilakukan pada 2 keluarga dilakukan selama 20 menit 


\section{Prosiding Seminar Nasional Kesehatan $\mathbf{2 0 2 1}$ Lembaga Penelitian dan Pengabdian Masyarakat Universitas Muhammadiyah Pekajangan Pekalongan}

per harinya, dalam satu hari hanya dilakukan satu kali tindakan kompres hangat menggunakan jahe merah.

\section{Kesimpulan}

Hasil penerapan terapi kompres hangat menggunakan jahe merah untuk menurunkan skala nyeri pada 2 lansia dengan gout arhtrtitis terjadi perubahan penurunan skala nyeri. Tindakan tersebut dilakukan selama 20 menit per harinya, sehari dilakukan tindakan satu kali terapi kompres hangat menggunakan jahe merah. Tindakan kompres hangat menggunakan jahe merah ini memberikan manfaat untuk menurunkan skala nyeri pada penderita gout arhtrtitis jika dilakukan secara rutin, terlebih lagi jika klien juga bisa menjaga pola makan dan mengatur gaya hidup seharihari karena tingginya kadar gout arhtrtitis akan menyebabkan peningkatan intensitas nyeri. Upaya yang dilakukan untuk menurunkan intensitas nyeri selain terapi kompres hangat menggunakan jahe merah yaitu berupa pemilihan makanan dan menghindari makanan yang tinggi purin yang bisa memicu peningkatan kadar gout arhtrtitis.

\section{Referensi}

[1] Padila, Buku Ajar Keperawatan Gerontik. Yogyakarta: Nuha Medika, 2017.

[2] R. Haryono \& S. Setianingsih, "Rematik dan Asam Urat," Awas Musuh-musuh Anda Setelah Usia 40 Tahun. Yogyakarta: Gosyen Publishing, 2013, 24-25.

[3] Kementrian Kesehatan Republik Indonesia., 2018. Laporan Nasional Rikerdas 2018. [Online] Available at: http://kesmas.kemkes.go.id[Accessed 8 Januari 2021].

[4] Ilham., 2020. Pengaruh Kompres Hangat Menggunakan Jahe Merah Terhadap Penurunan Skala Nyeri Pada Penderita Gout Arthtritis. Bina Generasi; Jurnal Kesehatan., Volume 11(2), pp. 14-19. [Online] Available at:

http://download.garuda. ristekdikti.go.id/article.php?article $=148813 \&$ val $=12513 \&$ title=pengaruh\%20kompres\%20hangat\%20menggunakan\%20jahe $\% 20$ merah $\%$ 20terhadap\%20penurunan\%20skala\%20nyeri\%20pada\%20penderita\%20pender ita\%20gout\%20arthtritis[Accessed 19 Desember 2020].

[5] R. Radharani," Kompres Jahe Hangat dapat Menurunkan Intensitas Nyeri pada Pasien Gout Arthtritis." Jurnal IImiah Kesehatan Sandi Husada, Volume 11(1), pp. 573-576, Juni 2020. 